\title{
GAMBARAN TINGKAT PENGETAHUAN REMAJA TENTANG HIV/AIDS DI SMA N 1 SELEMADEG
}

\author{
Desak Made Firsia Sastra Putri ${ }^{1,2}$, Desak Gede Yenny Apriani ${ }^{1,2}$, Ni Luh Gede Yunia Dewi ${ }^{1,2}$ \\ ${ }^{1}$ Prodi S1 Keperawatan Ners, ${ }^{2}$ STIKES Advaita Medika Tabanan \\ Korespondensi penulis: firshasastra86@gmail.com
}

\begin{abstract}
Abstrak
Latar Belakang: Masa remaja diasosiasikan dengan masa transisi dari anak-anak menuju dewasa. Perubahan fisik yang pesat dan perubahan hormonal merupakan pemicu masalah kesehatan remaja karena timbulnya dorongan motivasi seksual yang menjadikan remaja rawan terhadap penyakit dan masalah kesehatan reproduksi (kespro), kehamilan remaja dengan segala konsekuensinya yaitu hubungan seks pranikah, aborsi, Penyakit Menular Seksual (PMS), HIV-AIDS serta narkotika (Margaretha, 2012). Usia paling banyak penderita HIV AIDS adalah pada usia 25-39 tahun, sedangkan seseorang yang terpapar dengan virus HIV tidak akan menimbulkan gejala dalam waktu 5-10 tahun. Sehingga, kemungkinan terserang HIV pada saat usia remaja. Faktor resiko HIV tertinggi adalah hubungan seksual. Sedangkan pendidikan tentang seks sebagai salah satu upaya pencegahan HIV AIDS di Indonesia masih dianggap tabu dan belum mendapat perhatian yang cukup dari seluruh kalangan.

Tujuan: Mengetahui Gambaran Tingkat Pengetahuan Remaja Tentang HIV/AIDS di SMA N 1 Selemadeg

Metode: Metode penelitian ini menggunakan desain penelitian Deskriptif. Tehnik sampling yang dipakai dalam penelitian ini adalah tehnik purposive sampling dengan jumlah sampel 161 responden. Analisis yang digunakan dalam penelitian ini adalah analisis univariate yang menghasilkan distribusi frekuensi.

Hasil: Penelitian ini menunjukan berdasarkan tingkat pengetahuan responden tentang HIV/AIDS sebagian besar responden berpengetahuan kurang sebanyak 66 responden (41\%), cukup sebanyak 52 responden (32,3\%), baik sebanyak 43 responden $(26,7 \%)$.

Simpulan: Gambaran Tingkat Pengetahuan Remaja tentang HIV/AIDS di SMA N 1 Selemadeg didapatkan hasil tingkat pengetahuan remaja tentang HIV/AIDS kurang.
\end{abstract}

Kata kunci: Pengetahuan, Remaja, HIV/AIDS

\section{Pendahuluan}

Menurut World Health Organization (WHO) remaja adalah penduduk yang memiliki rentang usia 10-19 tahun, di dalam Peraturan Menteri Kesehatan RI Nomor 25 tahun 2014 remaja adalah penduduk dengan rentang usia 10-18 tahun dan menurut Badan Kependudukan Keluarga Berencana (BKKBN) (2014) remaja memiliki rentang usia 10-24 tahun dan belum menikah. Menurut WHO tahun 2014 dalam Kemenkes RI (2015), kelompok remaja di dunia diperkirakan berjumlah 1,2 milyar atau $18 \%$ dari jumlah penduduk dunia. Sensus Penduduk yang dilakukan pada tahun 2010 dalam Kemenkes RI (2015), jumlah kelompok remaja usia 10-19 tahun di Indonesia sebanyak 43,5 juta atau sekitar $18 \%$ jumlah penduduk. Berdasarkan data Dinas Kesehatan Provinsi Bali tahun 2018, jumlah remaja di provinsi bali sebanyak 326.146 orang.

Perubahan fisik yang pesat dan perubahan hormonal merupakan pemicu masalah kesehatan remaja karena timbulnya dorongan motivasi seksual yang menjadikan 
remaja rawan terhadap penyakit dan masalah kesehatan reproduksi (kespro), kehamilan remaja dengan segala konsekuensinya yaitu hubungan seks pranikah, aborsi, Penyakit Menular Seksual (PMS), HIV-AIDS serta narkotika (Margaretha, 2012). Pendataan yang dilakukan oleh World Health Organization (WHO) selama beberapa tahun terakhir menunjukkan bahwa kelompok remaja dan dewasa produktif usia 15-24 tahun, merupakan salah satu kelompok yang paling rentan terhadap HIV AIDS.

Indonesia merupakan negara di Asia Tenggara yang mempunyai orang hidup dengan HIV tertinggi. Pada tahun 2016 dilaporkan sebanyak 208.909 orang hidup dengan HIV. Angka itu sudah bertambah dari tahun sebelumnya yaitu sebanyak 191.073 orang. Jumlah orang yang terdiagnosa HIV terus bertambah dari tahun ke tahun (Kemenkes RI, 2014). Berdasarkan Komisi Penanggulangan AIDS (KPA) Provinsi Bali (2019), Bali termasuk dalam lima besar kasus HIV/AIDS dengan jumlah penderita HIV/AIDS mencapai 22.034 jiwa (1987November 2019). Dari jumlah kasus secara nasional, Bali menjadi urutan nomor lima setelah DKI Jakarta dan Jawa Barat. Berdasarkan Profil Kesehatan Kabupaten Tabanan (2018), menunjukkan bahwa kasus HIV terbanyak pada usia 25-49 tahun sebesar $72,4 \%$ dan kasus baru AIDS terbanyak pada usia 30-39 tahun sebesar 44\%.

Usia paling banyak penderita HIV AIDS adalah pada usia 25-39 tahun, sedangkan seseorang yang terpapar dengan virus HIV tidak akan menimbulkan gejala dalam waktu 5-10 tahun. Sehingga, kemungkinan terserang HIV pada saat usia remaja. Faktor resiko HIV tertinggi adalah hubungan seksual. Sedangkan pendidikan tentang seks sebagai salah satu upaya pencegahan HIV AIDS di Indonesia masih dianggap tabu dan belum mendapat perhatian yang cukup dari seluruh kalangan. Pendidikan seks harus dilakukan sedini mungkin sejak anak mulai mengerti dan dapat melakukan hubungan seks. Usia 15-24 tahun merupakan usia yang rentan terinfeksi HIV sehingga membutuhkan pengetahuan yang cukup tentang seksualitas (Vivi, 2014).

Resiko HIV pada remaja disebabkan oleh beberapa faktor yaitu, umur , tingkat pendidikan, tingkat pengetahuan, dan sikap. Salah satu diantara faktor-faktor tersebut ialah tingkat pengetahuan. Pengetahuan sangat berpengaruh terhadap terbentuknya sikap seseorang karena ternyata sikap yang didasari oleh pengetahuan lebih baik daripada sikap yang tidak didasari oleh pengetahuan (Dona, 2020). Untuk mengatasi HIV/AIDS dikalangan remaja dan dewasa muda, sangat penting kita mengulas tentang apa yang mereka ketahui tentang HIV/AIDS. Remaja ingin tahu lebih banyak tentang pencegahan HIV dan program pencegahan dikembangkan secara khusus untuk remaja dan dewasa muda yang HIV positif (Noviana, 2013).

Menurut penelitian Siti, et al (2017) menunjukkan bahwa pengetahuan siswa SMA tentang HIV/AIDS sebanyak 5 responden $(5,88 \%)$ dengan kriteria baik, 36 responden $(42,35 \%)$ cukup dan 44 responden $(51,76 \%)$ kurang. Sejalan dengan penelitian Nurul (2017) menunjukkan bahwa pengetahuan siswa SLTA tentang HIV/AIDS di SMA Gajah Mada Bandar Lampung dalam kategori baik yaitu sebanyak 45 responden $(20,7 \%)$, kategori cukup sebanyak 65 responden $(29,8 \%)$, dan kategori kurang sebanyak 108 responden $(49,5 \%)$. Hal ini dikarenakan pengetahuan HIV AIDS yang rendah, penggunaan kondom yang rendah dan tidak tepat, serta terbatasnya sarana pelayanan kesehatan reproduksi dan seksual ramah remaja.

Berdasarkan data dari Dinas Kesehatan Kabupaten Tabanan tahun 2019 dengan sumber data dari Klinik VCT Pelangi Tabanan menyatakan bahwa kasus HIV/AIDS terbanyak terdapat pada Kecamatan Tabanan, Kecamatan Selemadeg, dan Kecamatan Kediri. Adapun kasus di Kecamatan Selemadeg tercatat 9 kasus sedangkan menurut data yang didapat dari Puskemas Selemadeg hanya tercatat 2 kasus di tahun 2019 (Puskesmas Selemadeg, 2019). 
Salah satu SMA/SMK di kecamatan Selemadeg yaitu SMA Negeri 1 Selemadeg. Hasil studi pendahuluan yang dilakukan peneliti pada bulan Juli 2020 di SMA N 1 Selemadeg mengenai tingkat pengetahuan siswa SMA tentang HIV/AIDS dengan 10 responden, didapatkan hasil 8 siswa mengatakan belum begitu paham tentang HIV/AIDS sedangkan 2 siswa orang sudah mengetahui gambaran tentang HIV/AIDS dan cara-cara penularan HIV/AIDS. Pada saat ditanya mengenai penularan HIV/AIDS melalui hubungan seks dan narkoba, siswa cenderung menjawab dengan malu-malu dan kurang begitu paham. Sebagian besar siswa mengatakan lebih banyak mendengar tentang HIV/AIDS dari buku pelajaran dan posterposter di fasilitas kesehatan. Berdasarkan hal tersebut, peneliti tertarik untuk meneliti Gambaran Tingkat Pengetahuan Remaja Tentang HIV/ AIDS di SMA Negeri 1 Selemadeg.

\section{Metode Penelitian}

Desain penelitian yang digunakan pada penelitian ini adalah non eksperimen, yaitu dengan penelitian deskriptif. Penelitian ini adalah jenis penelitian kuantitatif dengan menggunakan pendekatan analisis deskriptif yaitu menggambarkan data yang diperoleh menyangkut keadaan subjek atau fenomena dari sebuah populasinya dimana pengumpulan data dilakukan pada satu titik waktu yang diteliti selama satu periode pengumpulan data. Penelitian ini dilakukan di SMA N 1 Selemadeg pada tanggal 14-20 September 2020. Populasi pada penelitian ini adalah remaja kelas XI di SMA N 1 Selemadeg yang berjumlah 270 orang. Pengambilan sampel pada penelitian ini dilakukan dengan teknik Non Probability Sampling dengan cara Purposive Sampling (Nursalam, 2015). Jumlah sampel yang akan diteliti yaitu 161 orang. Alat pengumpulan data yang digunakan dalam penelitian ini adalah kuesioner, yaitu kuesioner pengetahuan HIV/AIDS (Lia, 2015). Pada kuesioner pengetahuan HIV/AIDS tersebut dilakukan uji validitas dan reliabilitas pada tanggal 5 Agustus 2020 di SMK N 1 Tabanan dengan jumlah 20 responden. Semua item pernyataan dinyatakan valid dengan menggunakan bantuan SPSS. Uji statistik dilakukan untuk mengetahui gambaran tingkat pengetahuan remaja terhadap HIV/AIDS di SMA N 1 Selemadeg. Uji statistik yang digunakan adalah Statistik Deskriptif dengan menggunakan program komputer (SPSS).

\section{Hasil dan Pembahasan}

Tabel 1 Karakteristik Responden Berdasarkan Umur Remaja di SMA N 1 Selemadeg

\begin{tabular}{lll}
\hline Umur & Frekuensi (f) & Persentase (\%) \\
\hline 15 tahun & 9 & 5,6 \\
16 tahun & 105 & 65,2 \\
17 tahun & 42 & 26,1 \\
18 tahun & 5 & 3,1 \\
\hline Jumlah & 161 & 100 \\
\hline
\end{tabular}

Tabel 2 Karakteristik Responden Berdasarkan Jenis Kelamin Remaja di SMA N 1 Selemadeg

\begin{tabular}{lll}
\hline Jenis Kelamin & Frekuensi (f) & Persentase (\%) \\
\hline Laki-Laki & 66 & 41 \\
Perempuan & 95 & 59 \\
\hline Jumlah & 161 & 100 \\
\hline
\end{tabular}


e-ISSN : 2614-5685

p-ISSN : 2614-5421

Tabel 3 Karakteristik Responden Berdasarkan Tingkat Pendidikan Orang Tua Remaja di SMA N 1 Selemadeg

\begin{tabular}{lllll}
\hline & \multicolumn{2}{l}{ Pendidikan Ayah } & \multicolumn{2}{l}{ Pendidikan Ibu } \\
\hline $\begin{array}{l}\text { Tingkat } \\
\text { Pendidikan }\end{array}$ & $\begin{array}{l}\text { Frekuensi } \\
\text { (f) }\end{array}$ & $\begin{array}{l}\text { Persentase } \\
(\%)\end{array}$ & $\begin{array}{l}\text { Frekuensi } \\
\text { (f) }\end{array}$ & $\begin{array}{l}\text { Persentase } \\
(\%)\end{array}$ \\
\hline Perguruan Tinggi & 22 & 13,7 & 17 & 10,6 \\
SMA/SMK & 99 & 61,5 & 87 & 54 \\
SMP & 21 & 13 & 35 & 21,7 \\
SD & 18 & 11,2 & 20 & 12,4 \\
Tidak Sekolah & 1 & 0,6 & 2 & 1,2 \\
\hline Jumlah & 161 & 100 & 161 & 100 \\
\hline
\end{tabular}

Tabel 4 Karakteristik Responden Berdasarkan Pekerjaan Orang Tua Remaja di SMA N 1 Selemadeg

\begin{tabular}{lllll}
\hline & \multicolumn{2}{l}{ Pekerjaan Ayah } & \multicolumn{2}{l}{ Pekerjaan Ibu } \\
\hline Jenis Pekerjaan & $\begin{array}{l}\text { Frekuensi } \\
\text { (f) }\end{array}$ & $\begin{array}{l}\text { Persentase } \\
(\mathbf{\%})\end{array}$ & $\begin{array}{l}\text { Frekuensi } \\
\text { (f) }\end{array}$ & $\begin{array}{l}\text { Persentase } \\
(\%)\end{array}$ \\
\hline PNS & 17 & 10,6 & 11 & 6,8 \\
Karyawan Swasta & 33 & 20,5 & 23 & 14,3 \\
Wiraswasta/Pengusaha & 41 & 25,5 & 42 & 26,1 \\
Petani/Pekebun & 62 & 38,5 & 53 & 32,9 \\
Lainnya & 8 & 5 & 32 & 19,9 \\
\hline Jumlah & 161 & 100 & 161 & 100 \\
\hline
\end{tabular}

Tabel 5 Karakteristik Responden Berdasarkan Sumber Informasi Tentang HIV/AIDS Remaja di SMA N 1 Selemadeg

\begin{tabular}{lll}
\hline Sumber Informasi HIV/AIDS & Frekuensi (f) & Persentase (\%) \\
\hline Media Elektronik & 108 & 67,1 \\
Penyuluhan & 17 & 10,6 \\
Sekolah & 36 & 22,3 \\
\hline Jumlah & 161 & 100 \\
\hline
\end{tabular}

Tabel 6 Gambaran Tingkat Pengetahuan Remaja Tentang HIV/AIDS di SMA N 1 Selemadeg

\begin{tabular}{lll}
\hline Tingkat Pengetahuan & Frekuensi (f) & Persentase (\%) \\
\hline Kurang & 66 & 41 \\
Cukup & 52 & 32,3 \\
Baik & 43 & 26,7 \\
\hline Jumlah & 161 & 100 \\
\hline
\end{tabular}

Dari Tabel 1 di atas dapat dilihat bahwa responden sebagian besar berumur 16 tahun sebanyak 105 orang $(65,2 \%)$, dan sebagian kecil berumur 18 tahun sebanyak lima orang $(3,1 \%)$. Dari Tabel 2 di atas dapat dilihat bahwa responden sebagian besar berjenis kelamin perempuan sebanyak 95 orang $(59 \%)$ dan yang berjenis kelamin laki-laki sebanyak 66 orang (41\%). Dari Tabel 3 di atas dapat dilihat bahwa sebagian besar pendidikan orang tua (ayah) responden adalah SMA/SMK sebanyak 99 orang $(61,5 \%)$, dan terkecil ada yang tidak sekolah sebanyak satu orang $(0,6 \%)$. Dilihat dari pendidikan orang tua (ibu) responden menunjukkan bahwa sebagian besar memiliki pendidikan SMA/SMK sebanyak 87 orang (54\%), dan yang terkecil tidak sekolah sebanyak 2 orang $(1,2 \%)$.

Dari Tabel 4 di atas dapat dilihat bahwa sebagian besar pekerjaan orang tua (ayah) responden adalah petani/pekebun sebanyak 62 orang (38,5\%), dan sebgaian kecil lainnya sebanyak 8 orang $(5 \%)$. Dilihat dari pekerjaan orang tua (ibu) responden menunjukkan bahwa sebagian besar adalah petani/pekebun sebanyak 53 orang $(32,9 \%)$, dan sebagian kecil PNS sebanyak 11 orang $(6,8 \%)$. Dari Tabel 5 di atas dapat dilihat bahwa sebagian besar responden mendapat 
informasi tentang HIV/AIDS dari media elektronik sebanyak 108 orang $(67,1 \%)$, dan sebagian kecil dari penyuluhan sebanyak 17 orang (10,6\%). Tabel 6 di atas menggambarkan bahwa dari 161 responden, sebanyak 66 orang (41\%) mempunyai pengetahuan kurang, dan sebanyak 43 orang $(26,7 \%)$ mempunyai pengetahuan baik.

Umur mayoritas responden dalam penelitian ini adalah 16 tahun sebanyak 105 orang $(65,2 \%)$. Sejalan dengan penelitian yang dilakukan Lia (2015) didapatkan responden yang paling banyak yaitu berumur 16 tahun sebesar 56\%. Umur merupakan salah satu faktor pencetus yang dapat menggambarkan kematangan seseorang baik secara fisik, psikis, dan sosial.Bertambahnya umur seseorang dapat mengalami perubahan baik secara fisik maupun psikologis (mental). Jadi dapat disimpulkan bahwa umur mempengaruhi seseorang dalam berpikir dan menerima informasi. Semakin bertambahnya umur maka semakin taraf berpikir seseorang menjadi semakin matang dan dewasa.

Berdasarkan hasil yang didapatkan yaitu sebagian besar responden berjenis kelamin perempuan sebanyak 95 orang (59\%). Hal ini sejalan dengan penelitian Kulliyah (2018) menunjukkan bahwa 149 responden dengan proporsi sebanyak $56 \%$ berjenis kelamin perempuan. Jenis kelamin dalam hubungannya dengan HIV/AIDS lebih mengarah kepada pergaulan. Laki-laki cenderung lebih cepat terbawa dalam pergaulan lingkungan luar seperti ajakan teman untuk merokok, narkoba, dan seks bebas. Semakin banyak bergaul dengan lingkungan luar semakin tinggi tingkat pengetahuannya, tetapi juga semakin berisiko pada hal-hal negative untuk ikut terbawa dengan lingkungan yang berdampak pada kesehatan misalnya resiko tinggi untuk terkena HIV/AIDS (Siregar, 2014). Untuk mendapatkan informasi tentang masalah seksual, anak perempuan lebih senang membaca daripada anak laki-laki yang hanya senang bermain (Hurlock, 2003). Jadi dapat disimpulkan pengetahuan seseorang tidak selalu dapat diukur berdasarkan jenis kelamin melainkan hal tersebut tergantung dari seberapa banyak informasi yang didapatkan.

Sebagian besar pendidikan orang tua (ayah) responden adalah SMA/SMK sebanyak 99 orang $(61,5 \%)$ begitu pula pendidikan orang tua (ibu) responden juga menunjukkan bahwa sebagian besar memiliki pendidikan SMA/SMK sebanyak 87 orang (54\%). Hal ini sejalan dengan penelitian yang dilakukan Lia (2015) yang menunjukkan bahwa pendidikan orang tua responden sebagian besar adalah SMA sebanyak 23 orang atau 46\%. Menurut Mubarak (2017) Tidak dapat dipungkiri bahwa makin tinggi pendidikan seseorang semakin mudah pula mereka menerima informasi, dan pada akhirnya makin banyak pula pengetahuan yang dimilikinya dan begitu sebaliknya. Namun pada hasil penelitian didapatkan sebagian besar tingkat pengetahaun remaja kurang, hal ini bisa disebabkan karena pendidikan orangtua yang setingkat SMA/SMK tidak menjamin tingkat pengetahuan anaknya, orangtua yang pendidikannya tinggi belum tentu bisa memberikan informasi kesehatan yang tepat tentang HIV/AIDS pada anaknya, bisa saja disebabkan oleh kesibukan bekerja orangtua yang jarang bertemu dengan anaknya.

Berdasarkan hasil yang didapatkan sebagian besar pekerjaan orang tua (ayah) responden adalah petani/pekebun sebanyak 62 orang $(38,5 \%)$ dan pekerjaan orang tua (ibu) responden juga menunjukkan bahwa sebagian besar adalah petani/pekebun sebanyak 53 orang $(32,9 \%)$. Menurut Soekanto (2012) salah satu faktor yang mempengaruhi tingkat pengetahuan adalah sosial ekonomi. Bila ekonomi keluarga baik, maka tingkat pengetahuan meningkat. Jadi dapat disimpulkan bahwa tingkat pengetahuan seseorang tentang HIV/AIDS dipengaruhi oleh keadaan sosial ekonomi orang tersebut. Adapun perbedaan mayoritas pekerjaan orang tua responden di atas dapat disebabkan oleh faktor demografi dari tempat penelitian masing-masing.

Mayoritas responden mendapat informasi tentang HIV/AIDS dari media elektronik sebanyak 108 orang $(67,1 \%)$ dimana media 
elektronik yang dimaksud ini yaitu internet dan TV. Sejalan dengan penelitian yang dilakukan Lia (2015) menunjukkan bahwa sebagian besar responden memperoleh informasi tentang HIV/AIDS melalui internet sebanyak 22 orang atau 44\%. Responden yang memiliki pengetahuan kurang dari internet disebabkan karena tidak mampu memilah mana informasi yang benar dan tidak benar sehingga menyerap informasi yang salah tentang HIV/AIDS. Menurut Dona (2020) responden yang mendapatkan sumber informasi dari non nakes berpeluang 3,9 kali memiliki pengetahuan kurang dalam pencegahan HIV AIDS dibandingkan responden yang mendapatkan sumber informasi dari nakes. Informasi yang didapatkan remaja sebagain besar didapatkan dari non tenaga kesehatan. Informasi yang di dapatkan dari non tenaga kesehatan bisa menyebabkan kurangnya pengetahuan remaja tentang HIV AIDS dikarenakan informasi yang didapatkan remaja tidak didukung dengan data yang jelas dan akurat.

Berdasarkan hasil yang didapatkan bahwa sebagian besar mempunyai pengetahuan kurang tentang HIV/AIDS sebanyak 66 orang (41\%). Hal ini sejalan dengan penelitian yang dilakukan Siti, et al (2017) yang juga menunjukkan bahwa sebagian besar siswa memiliki pengetahuan kurang 44 orang $(51,76 \%)$. Begitu pula sejalan dengan penelitian yang dilakukan Stella, et al (2017) memperlihatkan bahwa pemahaman tentang HIV/AIDS dari para remaja masih kurang. Pada penelitian ini didapatkan hasil sebagian besar pengetahuan kurang, hal ini karena kurangnya minat dan ketertarikan remaja untuk mendapatkan informasi mengenai HIV/AIDS sehingga responden dalam penelitian ini tidak mengetahui lebih jauh tentang HIV / AIDS. Menurut peneliti karena kurangnya sumber informasi yang mereka dapatkan seperti penyuluhan dari lembaga pendidikan atau kesehatan, jadi keterpaparan informasi melalui media massa seperti televisi dan internet berpengaruh terhadap pemahaman remaja tentang pentingnya perlindungan diri terhadap HIV/AIDS dan berdampak pada sikap remaja dalam menyikapi pergaulan remaja terhadap HIV/AIDS. Jadi, tingkat pengetahuan remaja tentang HIV/AIDS dapat dipengaruhi oleh beberapa faktor yaitu dari segi umur, pekerjaan orang tua dan sumber informasi yang digunakan untuk memperoleh pengetahuan tersebut. Sumber pengetahuan yang benar dan tepat dan cara menerima informasi tentang HIV/AIDS menjadi salah satu poin penting dalam upaya menghindari penularan HIV.

\section{Simpulan}

Berdasarkan hasil penelitian tentang gambaran tingkat pengetahuan remaja tentang HIV/AIDS di SMA N 1 Selemadeg terhadap 161 responden dapat disimpulkan sebagai berikut:

a. Sebagian besar responden berumur 16 tahun yaitu 105 orang $(65,2 \%)$.

b. Sebagian besar responden berjenis kelamin perempuan yaitu 95 orang $(59 \%)$.

c. Sebagian besar pendidikan orang tua (ayah) responden yaitu SMA/SMK sebanyak 99 orang $(61,5 \%)$ dan pendidikan orang tua (ibu) yaitu SMA/SMK sebanyak 87 orang (54\%).

d. Sebagian besar pekerjaan orang tua (ayah) responden yaitu petani/pekebun sebanyak 62 orang $(38,5 \%)$ dan pekerjaan orang tua (ibu) yaitu petani/pekebun sebanyak 53 orang $(32,9 \%)$.

e. Sebagain besar responden mendapat informasi tentang HIV/AIDS dari media elektronik yaitu 108 orang $(67,1 \%)$.

f. Sebagian besar responden memiliki tingkat pengetahuan kurang yaitu 66 orang $(41 \%)$.

\section{Referensi}

Badan Koordinasi Keluarga Berencanan Nasional. Modul Pelatihan Konseling Kesehatan Reproduksi Remaja Bagi Calon Konselor Sebaya. Jakarta: BKKBN; 2014

Dinas Kesehatan Kabupaten Tabanan. 2018. Profil Kesehatan Kabupaten Tabanan 
tahun 2018. Dikses tanggal 14 Juli 2020

Dinas Kesehatan Provinsi Bali. 2018. Profil Kesehatan Provinsi Bali Tahun 2018. Bali: Dinas Kesehatan Porvinsi Bali

Dona, Martilova. 2020. Faktor Yang Mempengaruhi Pengetahuan Remaja Dalam Pencegahan Hiv Aids Di Sma N 7 Kota Pekanbaru. Diakses tanggal 9 Juli 2020

Hurlock, E.B. 2013. Psikologi perkembangan (Suatu perkembangan sepanjang Rentan kehidupan). Jakarta: Erlangga.

Lia, Evi Diana. 2015. Tingkat Pengetahuan Remaja Putri Tentang Hiv/Aids Di Sma N 1 Cangkringan Yogyakarta Tahun 2015. Diakses tanggal 14 September 2020

Kementerian Kesehatan Republik Indonesia. Infodatin AIDS.pdf. 2014.

Kemenkes RI. 2015. Profil Kesehatan Indonesia tahun 2014.Jakarta : Kemenkes RI

Komisi Penanggulangan AIDS (KPA) Provinsi Bali. 2019. Kasus HIV/AIDS di Bali. Diakses tanggal 20 Juli 2020

Margareta. 2012. Psikopatologi dan Perilaku Beresiko Remaja. Jakarta. ECG

Mubarak, I. 2017. Promosi Kesehatan. Graha Ilmu : Yogyakarta

Noviana., Kesehatan Reproduksi Dan HIV/AIDS. Jakarta: CV. TransInfo Media, 2013

Nursalam. 2015. Metode Penelitian Ilmu Keperawatan Edisi 4. Jakarta: Salembang Medika

Nurul, Isnaini. 2017. Pengetahuan Siswa SLTA Tentnag HIV/AIDS di Sekolah Menengah Tingkat Atas (SMA) Gajah Mada Bandar Lampung Tahun 2017. Diakses tanggal 14 September 2020

Puskesmas Selemadeg. 2019. Data Kasus HIV/AIDS Tahun 2019.

Siregar. 2014. Karakteristik odha yang berkunjung ke klinik VCT Di RSUP H. Adam Malik Medan. Diakses tanggal 20 September 2020
Siti, Mardiyah, Catur Esty, \& Rizkia Amilia. 2017. Gambran Tingkat Pengetahuan Remaja Tentang HIV/AIDS di SMKN 3 Mataram. Diakses tanggal 12 Juli 2020.

Soekanto, 2010. "Sosiologi Suatu Pengantar". Jalarta: PT Raja Grafida Persada.

Stella, Soselisa, Henry Palandeng \& Lilian Andries. 2017. Gambaran Pengetahuan Remaja Tentnag HIV/AIDS di Pusat Pengembangan Anak ID-127 Kelurahan Ranomut Manado. Diakses tanggal 20 September 2020

WHO. HIV/AIDS Fact sheet Updated November 2017. http://www.who.int/mediacentre/factsh eets/fs360/en/. Diakses tanggal 14 September 2020 